CLINICAL STUDY

\title{
Increased levels of serum interleukin-12 in Graves' disease
}

\author{
Masaaki Tamaru, Bunzo Matsuura and Morikazu Onji \\ The Third Department of Internal Medicine, School of Medicine, Ehime University, Ehime, Japan \\ (Correspondence should be addressed to B Matsuura, The Third Department of Internal Medicine, School of Medicine, Ehime University, Shigenobu, \\ Ehime, 7910295, Japan; E-mail: bmatsu@m.ehime-u.ac.jp)
}

\begin{abstract}
We investigated serum total interleukin-12 (IL-12) levels in patients with Graves' disease and Hashimoto's thyroiditis. The serum IL-12 levels in Graves' disease were significantly increased in the hyperthyroid state, and were decreased during treatment with methimazole or propylthiouracil in accordance with the decline of free tri-iodothyronine $\left(\mathrm{T}_{3}\right)$ levels, free thyroxine levels and thyroidbinding inhibiting immunoglobulin (TBII) levels. When $\mathrm{T}_{3}$ was administered orally to normal subjects, serum IL-12 levels were slightly increased. These results suggest that IL-12 might be increased due to prolonged stimulation with thyroid hormone, and thyroid hormone by itself might be a selfperpetuating factor of Graves' disease via increased IL-12 production.
\end{abstract}

European Journal of Endocrinology 141 111-116

\section{Introduction}

Cytokines are likely to play an important role in autoimmune thyroid disease. These molecules, produced by both inflammatory cells and thyroid follicular cells $(1-5)$, are essential for $\mathrm{T}$ and $\mathrm{B}$ cell growth and differentiation, and may affect thyroid follicular cells directly, inducing expression of major histocompatibility complex (MHC) class II molecules and adhesion molecules (6-11). Interleukin-12 (IL-12) is a recently defined cytokine that was originally identified and purified from condition medium of Epstein-Barr virus (EBV)-transformed human lymphoblastoid cell lines $(12,13)$. IL-12 enhances the cytotoxic activities of natural killer (NK) cells and T cells, and induces the production of several cytokines, especially interferon- $\gamma$ $(\mathrm{IFN}-\gamma)(14)$. IL-12 has three secreted forms, heterodimeric p70, homodimeric $\mathrm{p} 4 \mathrm{O}_{2}$, and monomeric p40 $(15,16)$. Among these three forms, p40 is mainly secreted in vivo and in vitro $(16,17)$.

IL-12 has not been studied sufficiently in auto-immune thyroid disease in human and experimental animals (1820). To investigate a role of $\mathrm{IL}-12$ in autoimmune thyroid disease, we measured serum IL-12 levels in various functional states of autoimmune thyroid disease.

\section{Subjects and methods}

We studied 20 patients with Graves' disease (4 males and 16 females; mean age $34 \pm 16$ years, range $14-75$ years). All patients had been clinically thyrotoxic, with diffusely enlarged thyroid glands, elevated serum free thyroxine
$\left(\mathrm{T}_{4}\right)$ and tri-iodothyronine $\left(\mathrm{T}_{3}\right)$ levels, and increased ${ }^{99} \mathrm{~m}$ Tc uptake in the thyroid glands at the first visit to our hospital. They had been treated with methimazole (MMI) or propylthiouracil (PTU), and had then become euthyroid. Another 12 patients (all females; mean age $50 \pm 14$ years, range 20-76 years) had Hashimoto's thyroiditis, the diagnosis of which was confirmed by enlarged thyroid glands and thyroid function tests. All patients with Hashimoto's thyroiditis had been hypothyroid at the first visit, and had been treated with levothyroxine $\left(\mathrm{T}_{4}\right)$ and had become euthyroid. The clinical data of all patients are shown in Table 1. Twenty-three subjects who had normal thyroid function and no medical illness were studied as normal controls (12 males and 11 females; mean age $31 \pm 7$ years, range 23-50 years). Nine ( 7 males and 2 females; mean age $30 \pm 2$ years, range 24-42 years) of twenty-three control subjects were administered Liothyronine sodium ( $\mathrm{T}_{3}, 75 \mu \mathrm{g} /$ day) orally for 10 days. The percentage of smokers among patients with Graves' disease and Hashimoto's thyroiditis and in control subjects was $25 \%, 12 \%$, and $17 \%$ respectively. The rates of alcoholic habits in these 3 groups were also not significantly different. All patients and control subjects gave their informed consent before being enrolled in the study.

Serum thyrotropin (TSH) levels were measured with an IRMA kit (Eiken Chemical Co. Ltd, Tokyo, Japan) and free $\mathrm{T}_{4}$ and free $\mathrm{T}_{3}$ were measured with RIA kits (Ortho Clinical Diagnostics, Tokyo, Japan), while the serum thyroid-binding inhibiting immunoglobulin (TBII) was assessed with an RRA kit (Kodak diagnostics, Tokyo, Japan). Thyroglobulin antibody (TGAb) and microsomal 
Table 1 The clinical data of patients with Graves' disease and Hashimoto's thyroiditis.

\begin{tabular}{|c|c|c|c|c|c|}
\hline & \multicolumn{2}{|c|}{$\begin{array}{l}\text { Graves' disease } \\
\quad(n=20)\end{array}$} & \multicolumn{2}{|c|}{$\begin{array}{l}\text { Hashimoto's thyroiditis } \\
\qquad(n=12)\end{array}$} & \multirow{2}{*}{$\begin{array}{l}\text { Reference } \\
\text { range }\end{array}$} \\
\hline & Hyperthyroid & Euthyroid & Hypothyroid & Euthyroid & \\
\hline TSH (mU/l) & $<0.03$ & $1.75 \pm 2.06$ & $56 \pm 29$ & $2.9 \pm 2.1$ & $0.1-4.0$ \\
\hline Free $\mathrm{T}_{4}(\mathrm{pmol} / \mathrm{l})$ & $71.7 \pm 39.7$ & $14.1 \pm 2.5$ & $6.4 \pm 3.8$ & $15.3 \pm 2.5$ & $11.5-26.9$ \\
\hline Free $\mathrm{T}_{3}(\mathrm{pmol} / \mathrm{l})$ & $21.8 \pm 9.0$ & $4.4 \pm 0.7$ & $3.3 \pm 1.6$ & $5.8 \pm 1.3$ & $4.0-8.1$ \\
\hline TBII (\%) & $43 \pm 26$ & $8 \pm 10$ & ND & ND & $-7-12$ \\
\hline TGAb (+) (\%) & 20 & ND & 83 & ND & Negative \\
\hline $\operatorname{MCAb}(+)(\%)$ & 70 & ND & 91 & ND & Negative \\
\hline
\end{tabular}

ND, not determined.

antibody (MCAb) were measured by haemagglutination using commercial kits (Fuji Rebio Inc., Tokyo, Japan).

Serum total IL-12 levels were measured by an enzyme-linked immunosorbent assay (ELISA) using Predicta Total IL-12 kit (Genzyme Co., Cambridge, MA, USA). In this assay, a monoclonal antibody to human IL-12 was first immobilized onto the microtiter plates. Each sample or standard was added to each test well and incubated to allow any human IL-12 present to be bound by antibodies on the microtiter plate. The wells were washed and a biotinylated antibody to IL-12 was added which bound to the captured IL-12 during incubation. After washing, a horseradish peroxidaselabeled streptavidin reagent was added which attached to the biotin in the immune complex on the plate during incubation. Following incubation, the wells were washed and a substrate solution was added to the wells. The reaction was stopped by the addition of $1 \mathrm{~mol} / \mathrm{l} \mathrm{H}_{2} \mathrm{SO}_{4}$. The absorbance of each well was read at $450 \mathrm{~nm}$.

Data were expressed as the mean \pm one standard deviation (S.D.). Statistical analysis of the data was performed using paired $t$-test or Wilcoxon test, unpaired $t$-test or Mann-Whitney test, and Pearson's correlation test or Spearman's correlation test. A value of $P<0.05$ was considered to indicate statistical significance.

\section{Results}

\section{Serum IL-12 levels in autoimmune thyroid disease}

The mean serum IL-12 level in 23 control subjects was $150 \pm 51 \mathrm{pg} / \mathrm{ml}$. The mean serum IL-12 level in 20 patients with Graves' disease in the hyperthyroid state was $370 \pm 126 \mathrm{pg} / \mathrm{ml}$, and this was significantly decreased to $196 \pm 70 \mathrm{pg} / \mathrm{ml}$ in the euthyroid state after a 6- to 72-month treatment with MMI or PTU (Fig. 1). The changes in IL-12 levels and free $\mathrm{T}_{3}$ levels in 5 patients among 20 patients with hyperthyroid Graves' disease during treatment with MMI or PTU are shown in Fig. 2. The free $\mathrm{T}_{3}$ levels decreased rapidly; on the other hand the IL-12 levels decreased slowly. In patients with Hashimoto's thyroiditis, the mean IL-12 level was $91 \pm 59 \mathrm{pg} / \mathrm{ml}$ in the hypothyroid state, and it remained almost unchanged in the euthyroid state $(96 \pm 60 \mathrm{pg} /$ $\mathrm{ml})$. Moreover, the IL-12 levels in 20 patients with hyperthyroid Graves' disease were significantly increased compared with those in 55 euthyroid subjects, inclusive of 23 control subjects, 20 patients with euthyroid Graves' disease, and 12 patients with euthyroid Hashimoto's thyroiditis (IL-12 levels in

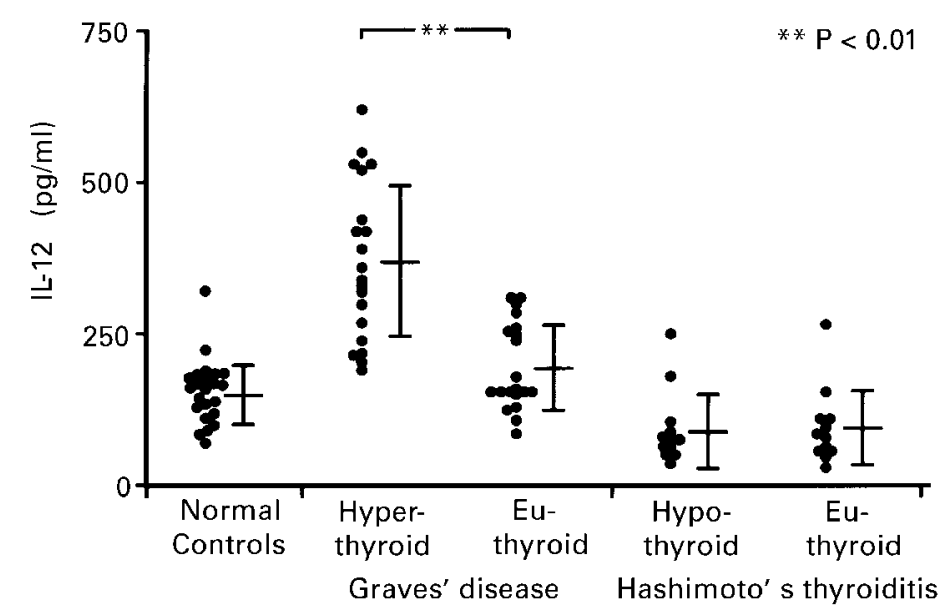

Figure 1 Serum IL-12 levels in each group (normal controls, $n=23$; Graves' disease, $n=20$; Hashimoto's thyroiditis, $n=12$ ). Serum IL-12 levels in Graves' disease were significantly decreased after treatment with $\mathrm{MMI}$ or PTU $\left({ }^{* *} P<0.01\right)$. Values are means \pm S.D. 
Figure 2 Clinical course in 5 patients with Graves' disease during treatment with MMI or PTU. (a) Free $\mathrm{T}_{3}$; (b) IL-12. Serum IL-12 levels gradually decreased during treatment with antithyroid drugs. Values are means \pm S.D.

hyperthyroid vs euthyroid state: $370 \pm 126$ vs $155 \pm 71 \mathrm{pg} / \mathrm{ml}, P<0.05$ ) (Figs 1, 2).

\section{Correlation between serum IL-12 levels and thyroid hormone levels}

The relationship between serum IL-12 levels and serum free $\mathrm{T}_{3}$, free $\mathrm{T}_{4}$ and TBII levels in 20 patients with Graves' disease during treatment with antithyroidal drugs was assessed. For free $\mathrm{T}_{3}(r=0.52)$, free $\mathrm{T}_{4}$ $(r=0.50)$, and TBII $(r=0.62)$, a significant positive correlation was noted (Fig. 3).

\section{Effects of administration of thyroid hormone}

To investigate the effect of IL-12 levels on thyroid hormone, $\mathrm{T}_{3}$ was administered to 9 control subjects. The serum free $\mathrm{T}_{3}$ levels increased from $4.5 \pm 0.4$ to $12.5 \pm 1.8 \mathrm{pmol} / \mathrm{l}$. The serum IL-12 levels significantly increased from $126 \pm 26$ to $163 \pm 48 \mathrm{pg} / \mathrm{ml}$ (Fig. 4).

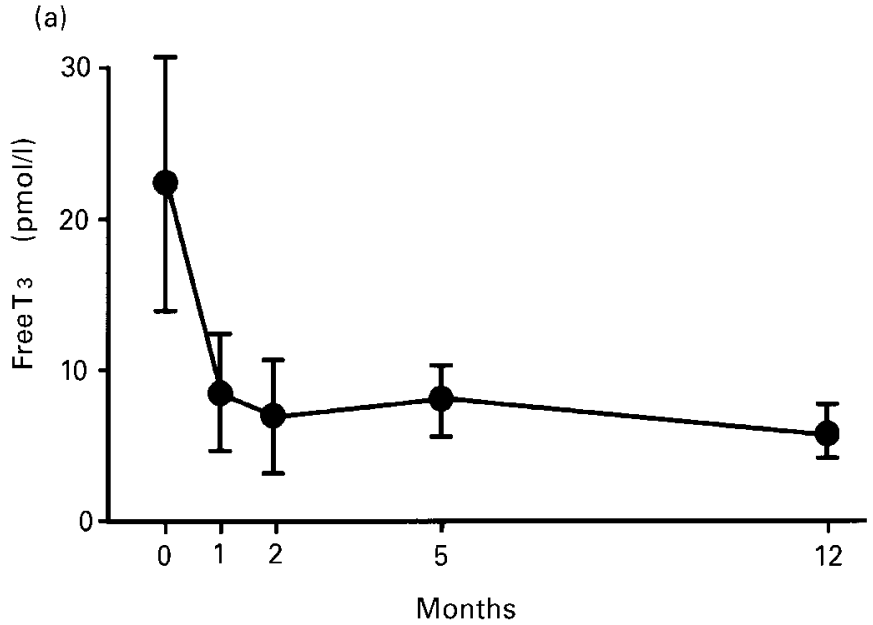

(b)

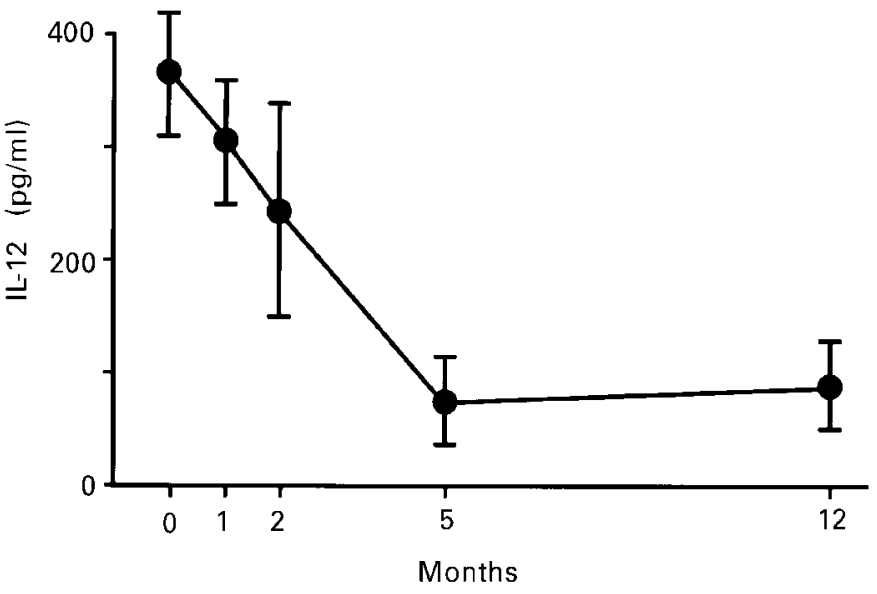

\section{Discussion}

A role of $\mathrm{IL}-12$ in autoimmune thyroid disease is uncertain. The most effective inducers of IL-12 production are bacteria, bacterial products (e.g. Staphylococcus aureus Cowan strain I, lipopolysaccharide), certain viruses (e.g. Herpes simplex virus) and intracellular parasites (e.g. Toxoplasma) $(21,22)$. Regarding the relation of IL-12 and thyroid disease, Zipris et al. have shown in BioBreeding (BB) autoimmune thyroiditisprone rats that IL-12 p40 gene expression increased in the thyroid gland with the progression of thyroiditis, implicating IL-12 in the perpetuation, if not the initiation, of the disease (19). Ajjan et al. have also shown IL-12 p40 expression in the thyroid gland with Hashimoto's thyroiditis and Graves' disease (18). The form of IL-12 for which a biological activity has been ascribed is p70. IL-12 p70 is composed of two covalently bound chains, p35 and p40 (12, 13). IL-12 p70, however, is least detected in vivo and in vitro among 

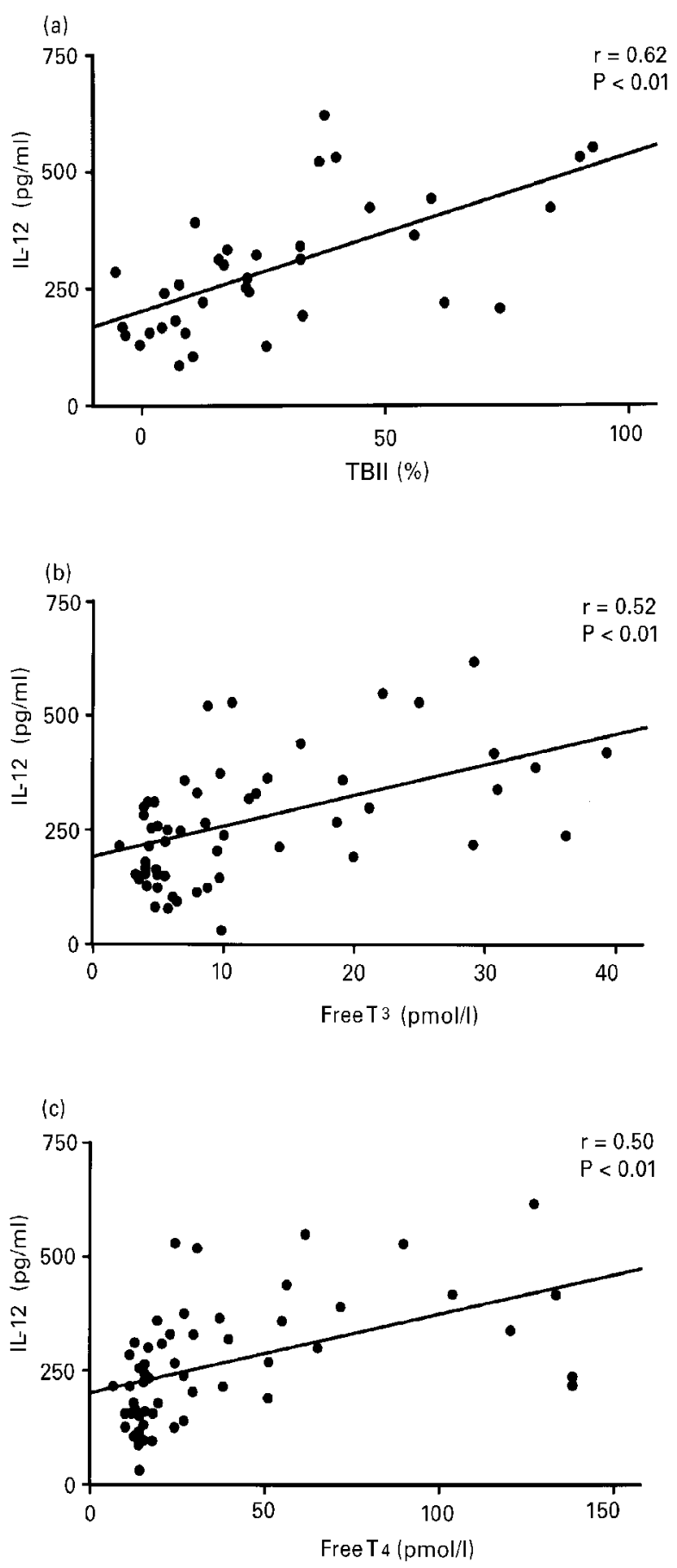

Figure 3 Correlation between IL-12 and (a) TBII, (b) free $\mathrm{T}_{3}$ and (c) free $T_{4}$ in Graves' disease at any available time point. A significant positive correlation was noted for these parameters $(P<0.01)$.

three secreted forms (p70, p40 2 , and p40), and has been detected 5- to 90-fold less than p40 (15-17, 23, 24). We first investigated serum IL-12 p70 levels in autoimmune thyroid disease by an ELISA kit (Genzyme Co.), but serum p70 levels were below the detection limit $(2 \mathrm{pg} / \mathrm{ml})$. Therefore, we measured total IL-12 levels. The serum IL-12 levels in patients with Graves' disease were significantly increased in the hyperthyroid state, and decreased slowly during treatment with antithyroidal drugs. Moreover, in normal subjects the serum IL-12 levels were slightly increased after administration of $\mathrm{T}_{3}$ for 10 days. Changes in serum IL-12 levels seemed to be delayed compared with those of serum thyroid hormones. These results suggest that thyroid hormone by itself might cause an increase in IL-12 levels, and that this effect might be caused by chronic stimulation with thyroid hormone.

IL-12 also plays an important role in IL-2 receptor (IL-2 R) expression and proliferation of T helper 1 (Th1), but not T helper 2 (Th2), clones as a second signal (25). In thyroid disease, we previously reported that the serum soluble IL-2 R levels in patients with Graves' disease in the hyperthyroid state were significantly increased (26). Recently, several investigators have reported a critical role for IL-12 in the pathogenesis of rodent models of Th1-mediated autoimmune diseases such as type 1 diabetes, multiple sclerosis, rheumatoid arthritis, inflammatory bowel disease, and acute graftversus-host disease (27-32). The expression of autoimmunity in rodent models has depended on a balance between populations of regulatory and effector $\mathrm{T}$ cells (19). The balance between autoreactive and regulatory cell populations has represented a balance between the Th1 and Th2 subsets $(33,34)$. The former have mediated proinflammatory reactions and secreted IFN- $\gamma$ and IL-2; the latter have subserved a suppressor function, secreted IL-4 and IL-10, and down-regulated a Th1 immune response. These subsets have functioned in an agonist/antagonist fashion, and it was possible that the outcome of an autoreactive process might reflect the balance between these two Th subtypes $(34,35)$. Recently, Braley-Mullen et al. have reported that IL-12 markedly increased IFN- $\gamma$ production but did not induce a shift to a Th1-dominant phenotype, as other Th1 and Th2 cytokines were generally unaffected and both Th1 and Th2 cytokines were expressed in recipient experimental thyroiditis (20). We investigated serum IL-10 levels in patients with autoimmune thyroid disease and control subjects with an ELISA kit (BioSource International Inc., Camarillo, CA, USA) and showed that they did not differ in any of the patients and control subjects (data not shown). These results suggest that IL-10 might not have effects on IL-12 production in autoimmune thyroid disease.

IL-12 plays a crucial role in the initiation and regulation of immune responses leading to IFN- $\gamma$ production, and neutralization of IL-12 exacerbates a variety of diseases $(21,36)$. Gorak et al. have advocated a model for NK-T-APC (antigen presenting cell) clusters forming the initiating microenvironment for innate and acquired immunity, following the study of infection with Leishmania (37). The model depicts both naïve $\mathrm{T}$ cell activation and IL-12-dependent NK cell activation 


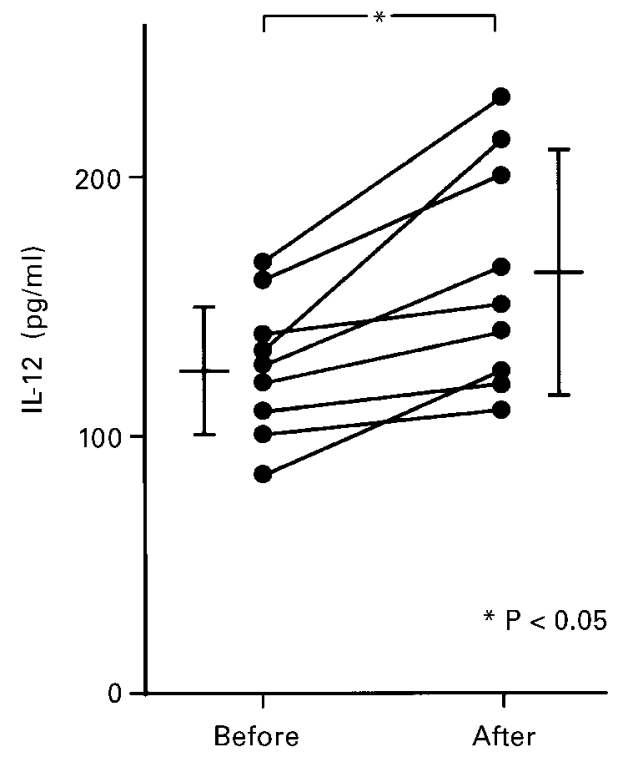

Figure 4 Effect of $T_{3}$ in 9 normal subjects. After administration of $\mathrm{T}_{3}$, serum IL-12 levels were significantly increased $\left({ }^{*} P<0.05\right)$. Values presented as means \pm S.D. are also shown.

occurring at the surface of an APC. CD40/CD40L and TCR/MHC interactions may regulate IL-12 production by APC, although the role of parasites and their products remains to be established (37). In the present study, the IL-12 levels in patients with Graves' disease were changed in accordance with the TBII levels, while the IL-12 levels in normal subjects were changed only by administration of thyroid hormone. As the TBII levels in Graves' disease during treatment with antithyroidal drugs were correlated with thyroid hormone levels, even though the IL-12 levels were changed with TBII levels, we thought that the IL-12 was not necessarily dependent on the immunological condition. These results suggest that IL-12 might effect the progression of Graves' disease, but not the initiation of this disease. Further investigation on the role of IL-12 in autoimmune thyroid disease appears to be necessary.

\section{References}

1 Del Prete GF, Vercelli D, Tiri A, Maggi E, Mariotti S, Pinchera A, Ricci M \& Romagnani S. In vivo activated cytotoxic T cells in the thyroid infiltrate of patients with Hashimoto's thyroiditis. Clinical and Experimental Immunology 198665 140-147.

2 Del Prete GF, Tiri A, de Carli M, Mariotti S, Pinchera A, Chretien I, Romagnani S \& Ricci M. High potential to tumor necrosis factor alpha (TNF- $\alpha$ ) production of thyroid infiltrating $\mathrm{T}$ lymphocytes in Hashimoto's thyroiditis: a peculiar feature of destructive thyroid autoimmunity. Autoimmunity 19894 267-276.

3 Watson PF, Pickerill AP, Davies R \& Weetman AP. Semiquantitative analysis of interleukin-1, interleukin-6 and interleukin-8 mRNA expression by human thyrocytes. Journal of Molecular Endocrinology 199515 11-21.

4 Grubeck-Loebenstein B, Buchan G, Chantry D, Kassal H, Londei M, Pirich K, Barrett K, Turner M, Waldhaual W \& Feldmann M.
Analysis of intrathyroidal cytokine production in thyroid autoimmune disease: thyroid follicular cells produce interleukin-1 and interleukin-6. Clinical and Experimental Immunology 198977 324-330.

5 Zheng RQ, Abney ER, Chu CQ, Field M, Maini RN, Lamb JR \& Feldmann M. Detection of in vivo production of tumor necrosis factor-alpha by human thyroid epithelial cells. Immunology 1992 75 456-462.

6 Todd I, Pujol-Borrell R, Hammond LJ, Bottazzo GF \& Feldmann M. Interferon- $\gamma$ induces HLA-DR expression by thyroid epithelium. Clinical and Experimental Immunology 198511 265-273.

7 Weetman AP \& Borysiewicz LK. Regulation of major histocompatibility complex class II antigen expression by the FRTL5 rat thyroid cell line. Journal of Endocrinology $1987115481-$ 487.

8 Weetman AP \& Rees AJ. Synergistic effects of recombinant tumor necrosis factor- $\alpha$ (TNF- $\alpha$ ) and $\gamma$-interferon $(\gamma$-IFN) on rat thyroidal cell growth and Ia antigen expression. Immunology $198863285-289$.

9 Weetman AP, Cohen SB, Makgoba MW \& Borysiewicz LK. Expression of an intercellular adhesion molecule, ICAM-1, by human thyroid cells. Journal of Endocrinology 1989122 185191.

10 Tandon N, Makgoba MW, Gahmberg CG \& Weetman AP. The expression and role in T cell adhesion of LFA-3 and ICAM-2 on human thyroid cells. Clinical Immunology and Immunopathology $19926430-35$.

11 Vargas F, Tolosa E, Sospedra M, Catalfamo M, Lucas-Martin A, Obiols G \& Pujol-Borrell R. Characterization of neural cell adhesion molecule (NCAM) expression in thyroid follicular cells: induction by cytokines and over-expression in autoimmune glands. Clinical and Experimental Immunology 199498 478-488.

12 Kobayashi M, Fitz L, Ryan M, Hewick RM, Clark SC, Chan S, Loudon R, Sherman F, Perussia B \& Trinchieri G. Identification and purification of natural killer cell stimulatory factor (NKSF): a cytokine with multiple biologic effects on human lymphocytes. Journal of Experimental Medicine 1989170 827-845.

13 Stern AS, Podlaski FJ, Hulmes JD, Pan YC, Quinn PM, Wolitzky AG, Familletti PC, Stremlo DL, Truitt T, Chizzonite R et al. Purification to homogeneity and partial characterization of cytotoxic lymphocyte maturation factor from human B-lymphoblastoid cells. Proceedings of the National Academy of Sciences of the USA $1990876808-6812$.

14 Manetti R, Parronchi P, Giudizi MG, Piccinni MP, Maggi E, Trinchieri G \& Romagnani S. Natural killer cell stimulatory factor (interleukin 12 (IL-12)) induces $\mathrm{T}$ helper type 1 (Th1)-specific immune responses and inhibits the development of IL-4-producing Th cells. Journal of Experimental Medicine 1993 177 1199-1204.

15 Ling P, Gately MK, Gubler U, Stern AS, Lin P, Hollfelder K, Su C, Pan YC \& Hakimi J. Human IL-12 p40 homodimer binds to the IL-12 receptor but does not mediate biologic activity. Journal of Immunology 1995154 116-127.

16 Zhang M, Gately MK, Wang E, Wolf SF, Lu S, Modlin RL \& Barnes PF. Interleukin 12 at the site of disease in tuberculosis. Journal of Clinical Investigation 199493 1733-1739.

17 D'Andrea A, Rengaraju M, Valiante NM, Chehimi J, Kubin M, Aste M, Chan SH, Kobayashi M, Young D, Nickbarg E et al. Production of natural killer cell stimulatory factor (interleukin 12) by peripheral blood mononuclear cells. Journal of Experimental Medicine $19921761387-1398$.

18 Ajjan RA, Watson PF \& Weetman AP. Detection of IL-12, IL-13, and IL-15 messenger ribonucleic acid in the thyroid of patients with autoimmune thyroid disease. Journal of Clinical Endocrinology and Metabolism 199782 666-669.

19 Zipris D, Greiner DL, Malkani S, Whalen B, Mordes JP \& Rossini AA. Cytokine gene expression in islets and thyroids of $\mathrm{BB}$ rats: IFN- $\gamma$ and IL-12 p40 mRNA increase with age in both diabetic and insulin-treated nondiabetic BB rats. Journal of Immunology $19961561315-1321$. 
20 Braley-Mullen H, Sharp GC, Tang H, Chen K, Kyriakos M \& Bicke JT. Interleukin-12 promotes activation of effector cells that induce a severe destructive granulomatous form of murine experimental autoimmune thyroiditis. American Journal of Pathology 1998152 1347-1358.

21 Trinchieri G. Interleukin-12: a proinflammatory cytokine with immunoregulatory functions that bridge innate resistance and antigen-specific adaptive immunity. Annual Review of Immunology $199513251-276$.

22 Halpern MD, Kurlander RJ \& Pisetsky DS. Bacterial DNA induces murine interferon-gamma production by stimulation of interleukin-12 and tumor necrosis factor-alpha. Cellular Immunology $199616772-78$.

23 Heinzel FP, Rerko RM, Ling P, Hakimi J \& Schoehaut DS Interleukin 12 is produced in vivo during endotoxemia and stimulates synthesis of gamma interferon. Infection and Immunology $1994624244-4249$.

24 Wysocka M, Kubin M, Vieira LQ, Ozmen L, Garotta G, Scott P \& Trinchieri G. Interleukin-12 is required for interferon-gamma production and lethality in lipopolysaccharide-induced shock in mice. European Journal of Immunology $199525672-676$.

25 Yanagida T, Kato T, Igarashi O, Inoue T \& Nariuchi H. Second signal activity of IL-12 on the proliferation and IL-2 R expression of T helper cell-1 clone. Journal of Immunology 1994152 4919-4928.

26 Nakanishi K, Taniguchi Y \& Ohta Y. Increased soluble interleukin 2 receptor levels in autoimmune thyroid disease. Acta Endocrinologica 1991125 253-258.

27 Trembleau S, Germann T, Gately MK \& Adorini L. The role of IL12 in the induction of organ-specific autoimmune diseases. Immunology Today 199516 383-386.

28 Leonard JP, Waldburger KE \& Goldman SJ. Prevention of experimental autoimmune encephalomyelitis by antibodies against interleukin 12. Journal of Experimental Medicine 1995181 381-386.
29 Germann T, Szeliga J, Hess H, Storkel S, Podlaski FJ, Gately MK, Schmitt E \& Rude E. Administration of interleukin 12 in combination with type II collagen induces severe arthritis in DBA/1 mice. Proceedings of the National Academy of Sciences of the USA 199592 4823-4827.

30 Neurath MF, Fuss I, Kelsall BL, Stuber E \& Strober W. Antibodies to interleukin 12 abrogate established experimental colitis in mice. Journal of Experimental Medicine 1995182 1281-1290.

31 Williamson E, Garside P, Baradley JA \& Mowat AM. IL-12 is a central mediator of acute graft-versus-host disease in mice. Journal of Immunology 1996157 689-699.

32 Seder RA, Kelsall BL \& Jankovic D. Differential roles for IL-12 in the maintenance of immune responses in infectious versus autoimmune disease. Journal of Immunology 1996157 2745-2748.

33 Rabinovitch A. Immunoregulatory and cytokine imbalances in the pathogenesis of IDDM: therapeutic intervention by immunostimulation. Diabetes $199443613-621$.

34 Liblau RS, Singer SM \& McDevitt HO. Th1 and Th2 CD4+T cells in the pathogenesis of organ-specific autoimmune diseases. Immunology Today 199516 34-38.

35 Paul WE \& Seder RA. Lymphocyte responses and cytokines. Cell $199476241-251$.

36 Biron CA \& Gazzinelli RT. Effects of IL-12 on immune responses to microbial infections: a key mediator in regulating disease outcome. Current Opinion in Immunology 19957 485-496.

37 Gorak PMA, Engwerda CR \& Kaye PM. Dendritic cells, but not macrophages, produce IL-12 immediately following Leishmania donovani infection. European Journal of Immunology 199828 687695.

Received 25 November 1998

Accepted 14 April 1999 